\title{
Effect of ammonia treatment of wheat straw with or without supplementation of potato protein on intake, digestion and kinetics of comminution, rumen degradation and passage in steers
}

\author{
BY S. J. OOSTING \\ Department of Animal Husbandry, Section Tropical Animal Production, Agricultural University, \\ P.O. Box 338, NL 6700 AH Wageningen, The Netherlands \\ AND P. J. M. VLEMMIX AND J. VAN BRUCHEM \\ Department of Animal and Human Physiology, Agricultural University, Haarweg 10, \\ NL 6709 PJ Wageningen, The Netherlands
}

(Received 12 October 1992 - Revised 16 August 1993 - Accepted 2 November 1993)

\begin{abstract}
Untreated wheat straw (UWS) or ammoniated wheat straw without (AWS) or with (AWSP) a supplement of potato protein of a low rumen degradability was fed to three steers according to a $3 \times 3$ Latin square design. All rations were supplemented with sugar-beet pulp and minerals. Voluntary organic matter intake (OMI, $\mathrm{g} / \mathrm{kg}^{6.75}$ per d) was $67 \cdot 8,76 \cdot 0$ and $80 \cdot 1$ for whole rations $(51 \cdot 1,59 \cdot 7$ and $59 \cdot 2$ for straw) for UWS, AWS and AWSP respectively, which was significantly higher for AWS and AWSP than for UWS. Organic matter digestibility (OMD, g/kg) was 561, 596 and 625 for the respective rations UWS, AWS and AWSP, also significantly higher for AWS and AWSP than for UWS. The increased voluntary intake and digestion of ammoniated wheat-straw-based rations were associated with a significantly higher potentially degradable fraction (D) of neutral detergent fibre (NDF) in offered straw (556 and $661 \mathrm{~g} / \mathrm{kg}$ for untreated and ammoniated wheat straw respectively) and in the rumen pool (469, 555 and $554 \mathrm{~g} / \mathrm{kg}$ for UWS, AWS and AWSP respectively). Isolated small rumen particles (retained on sieves with a pore size $<1.25$ and $>0.041 \mathrm{~mm}$ ) had a significantly lower D of NDF (average $588 \mathrm{~g} / \mathrm{kg}$ ) than isolated large rumen particles (average $663 \mathrm{~g} / \mathrm{kg}$ ). Fractional rates of degradation of NDF did not differ significantly either between untreated and ammonia-treated wheat straw offered (2.9 and $2.6 \% / \mathrm{h}$ respectively) or between rumen pools $(1.8,1.7$ and $2 \cdot 1 \% / \mathrm{h}$ for UWS, AWS and AWSP respectively). Rations based on ammoniated wheat straw had a significantly higher rumen $\mathrm{NH}_{3}-\mathrm{N}$ concentration than UWS. Although the rumen pool size of total contents differed significantly between treatments, those of dry and organic matter and of cell wall constituents were not significantly different. The proportion of rumen dry matter passing through a sieve with a pore size of $1.25 \mathrm{~mm}$ averaged 0.684 over rations (not significantly different between rations). Daily rumination ( $96 \mathrm{~min}$ ) and eating ( $52 \mathrm{~min})$ times/kg NDF ingested did not differ between rations. The rate of comminution of large particles estimated from the disappearance of indigestible NDF in large rumen particles from the rumen of animals without access to feed was 4.1, 6.3 and $7 \cdot 1 \% / \mathrm{h}$ for UWS, AWS and AWSP respectively. These values were not significantly different. The fractional rate of passage estimated from the faecal excretion of Cr-NDF was 5.4, 6.1 and 6.3\%/h for UWS, AWS and AWSP respectively (significantly higher for AWS and AWSP than for UWS) but the turnover rate of indigestible NDF did not differ between treatments.
\end{abstract}

Ammonia treatment: Wheat straw: Rate of passage: Rate of degradation: Rumen pool size

Straws, which are important basal feeds for ruminants in densely populated areas in the tropics, are characterized by a low feed intake and digestibility. Ammonia treatment 
and/or supplementation with nutrients limiting to the animal or its rumen microbes are means to increase digestibility and intake of the straw (Dias-da-Silva \& Sundstøl, 1986; Cottyn \& De Boever, 1988; Silva et al. 1989; Mason et al. 1990).

Intake of fibrous feeds and its regulation in ruminants is still far from sufficiently understood. Proposed regulation mechanisms vary from almost entirely metabolic to almost entirely physical. Recently, Ketelaars \& Tolkamp (1992) and Tolkamp \& Ketelaars (1992) proposed that feed intake is primarily governed by metabolic mechanisms optimizing the efficiency of energy utilization, thus keeping the noxious effects of oxygen radicals to a minimum and increasing longevity of the animal.

Alternatively, under temperate conditions Bosch et al. (1992) made an analysis of voluntary intake of roughage feeds in relation to the processing capacity of the reticulorumen as determined by its holding capacity or pool size and rate of feed turnover. The latter factor in turn comprises (1) the fractional rate of comminution of large particles into particles of a size which can potentially leave the reticulo-rumen, (2) the rate of fermentative degradation by the rumen microbes, and (3) the rate of passage of undegraded particles to the lower gut. For sheep and cattle, Kennedy \& Poppi (1984) indicated a critical particle size (CPS) of 0.89 and $1.17 \mathrm{~mm}$ respectively. In addition to that the functional specific gravity of the feed particles is a variable to be considered. Kaske et al. (1992) introduced particles of varying size and specific gravity into the rumen of sheep and concluded that in determining the probability of escape from the reticulo-rumen the specific gravity of particles is superior to their size. Only small particles with a density equal to or higher than 1.22 showed a high probability of leaving the reticulo-rumen.

The present paper describes rumen pool sizes and kinetics of turnover in cattle fed on low-quality fibrous feeds as basal diet. The objective of this study was to assess the kinetics of rumen processing of the feed under conditions which usually prevail in the tropics. Knowledge of the magnitude of the factors describing these various processes will allow the identification of those factors which primarily constrain rumen processing capacity of lowquality fibrous feeds. Based on this information a well documented approach could be designed aiming at improving ruminant production in the tropics on diets largely consisting of highly fibrous feeds, through the formulation of proper supplements in combination with chemical and/or physical treatment.

\section{MATERIAL AND METHODS \\ Animals and diets}

Three steers (breed Dutch Red and White) of about $500 \mathrm{~kg}$ live weight were fitted with a rumen cannula (Bar Diamond Inc., Parma, Idaho, USA; $100 \mathrm{~mm}$ internal diameter) in the dorsal rumen sac. The steers were kept in tie stalls during the experiment and were fed twice daily at 07.30 and 19.30 hours. Water was freely available.

The experiment was set up as a $3 \times 3$ Latin Square design with each experimental period lasting 3 weeks. Adaptation periods before each experimental period had a duration of 3 weeks. A time chart of measurements during each experimental period is given in Table 1.

Treatments allocated to the animals were: (1) ad lib. wheat straw supplemented with sugar-beet pulp (UWS), (2) ad lib. ammoniated wheat straw supplemented with sugar-beet pulp (AWS) and (3) ad lib. ammoniated wheat straw supplemented with sugar-beet pulp and potato protein (AWSP), a protein with a relatively low rumen degradability. Ad lib. intake was achieved by offering the animals at least $20 \%$ surplus straw. The straw offered was chopped by a grass cutter to a length of approximately $50 \mathrm{~mm}$. Ammonia treatment of the straw was done with anhydrous ammonia $(40 \mathrm{~kg} / 900 \mathrm{~kg}$ straw dry matter). The 
Table 1. Time chart of activities during an experimental period

\begin{tabular}{|c|c|c|c|}
\hline & \multicolumn{3}{|c|}{ Experimental week } \\
\hline & 1 & 2 & 3 \\
\hline $\begin{array}{l}\text { Fasting from } 09.00-18.00 \text { hours } \\
\text { Rumen evacuations }\end{array}$ & $\mathbf{m t} \mathbf{w}$ & $\begin{array}{l}\mathrm{mtw} \\
\mathrm{mtw}\end{array}$ & - \\
\hline $\begin{array}{l}\text { Passage rates } \\
\quad k_{l} \\
k_{p \text {-faeces }} \\
k_{p \text {-rumen }}\end{array}$ & $\begin{array}{l}\mathrm{mt} \\
\mathrm{t} w \mathrm{tf}\end{array}$ & $\begin{array}{l}m t \\
\mathrm{t} w \mathrm{w} t \mathrm{f} \\
\mathrm{mtw}\end{array}$ & - \\
\hline $\begin{array}{l}\text { Particle size distribution } \\
\text { Ingested straw } \\
\text { Faeces } \\
\text { Chewing behaviour } \\
\text { pH, VFA and } \mathrm{NH}_{3}-\mathrm{N} \\
\text { Intake and digestibility } \\
\text { Dacron bag }\end{array}$ & $\begin{array}{l}- \\
\mathrm{m} \\
\mathrm{m} t \mathrm{t} t \mathrm{fs} \\
- \\
-\end{array}$ & 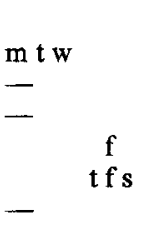 & $\begin{array}{l}-\frac{\mathrm{m}}{-} \\
\begin{array}{l}\mathrm{stw} \text { tfs } \\
\mathrm{tw} \text { t f s }\end{array}\end{array}$ \\
\hline
\end{tabular}

$\mathrm{s} \mathrm{m} \mathrm{twt} \mathrm{fs,} \mathrm{Sunday} \mathrm{through} \mathrm{to} \mathrm{Saturday;} k_{l}$, fractional rate of passage of the liquid phase of rumen contents; $k_{p \cdot \text { faeces }}$, fractional rate of the particulate phase of rumen contents, estimated from faecal excretion; $k_{p \text { ramen }}$, fractional rate of passage of the particulate phase of rumen contents, estimated from the decline in the rumen $\mathrm{Cr}$ pool; VFA, volatile fatty acids.

Table 2. Composition of the dietary supplements ( $g$ DM/kg DM)

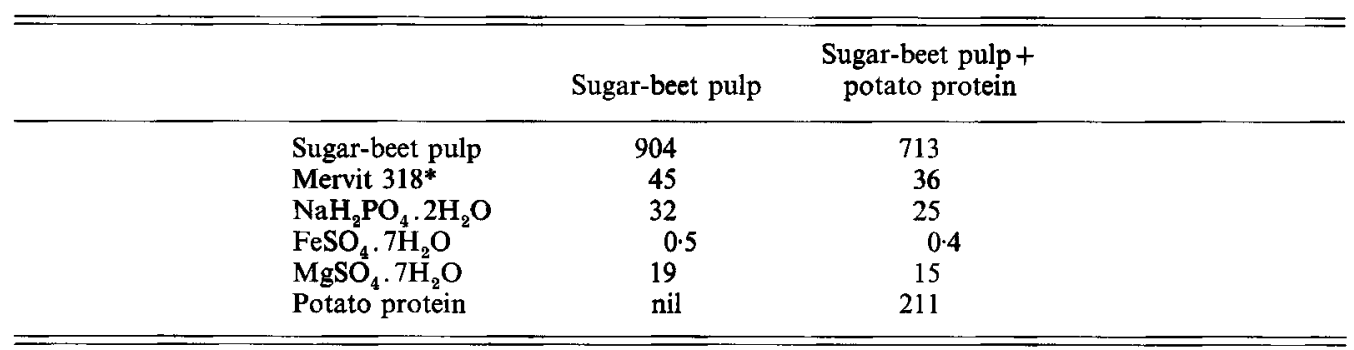

* Containing vitamins $\mathrm{A}$ and $\mathrm{D}_{3}$, and trace elements.

ammonia was injected into a pile of baled straw covered with two sheets of polythene $(0.15 \mathrm{~mm}$ thick). The duration of the treatment was 7 weeks.

Sugar-beet pulp, potato protein (Emsland-Stärke GmbH, Emlichheim, Germany) for diet AWSP, minerals and a commercially available mineral-vitamin mixture (Mervit 318; Premervo, Utrecht, The Netherlands) were offered as a pellet. The quantity of supplemental dry matter (DM) offered for rations UWS and AWS was $18.2 \mathrm{~g} / \mathrm{kg}^{0.75}$ per $\mathrm{d}$ and for ration AWSP $22.7 \mathrm{~g} / \mathrm{kg}^{0.75}$ per $\mathrm{d}$, thus achieving a DM intake (DMI) of sugar-beet pulp and minerals and vitamins of 16.5 and $1.7 \mathrm{~g} / \mathrm{kg}^{0.75}$ per $\mathrm{d}$ respectively, and an additional DMI of potato protein of $4.5 \mathrm{~g} / \mathrm{kg}^{0.75}$ per $\mathrm{d}$ for AWSP. The proportions of the various constituents in the supplements are given in Table 2 and the composition of the ration components is presented in Table 3.

Intake, digestibility and dacron bag analysis

Intake and digestibility were measured during a $10 \mathrm{~d}$ period in weeks 2 and 3 of each experimental period by total collection of feed residues and faeces. Urine was also collected 
Table 3. Chemical composition of ration components $(\mathrm{g} / \mathrm{kg}$ dry matter $(D M))$

\begin{tabular}{|c|c|c|c|c|}
\hline & $\begin{array}{c}\text { Untreated } \\
\text { wheat straw }\end{array}$ & $\begin{array}{l}\text { Ammoniated } \\
\text { wheat straw }\end{array}$ & $\begin{array}{l}\text { Sugar-beet } \\
\text { pulp }\end{array}$ & $\begin{array}{c}\text { Sugar-beet } \\
\text { pulp + potato } \\
\text { protein }\end{array}$ \\
\hline DM (g/kg) & 877 & 863 & 842 & 844 \\
\hline OM & 920 & 920 & 907 & 920 \\
\hline NDF & 797 & 786 & 301 & 250 \\
\hline $\mathrm{ADF}$ & 505 & 509 & 158 & 130 \\
\hline ADL & 65 & 60 & 13 & 12 \\
\hline $\mathbf{N}$ & 6 & 11 & 21 & 46 \\
\hline
\end{tabular}

OM, organic matter; NDF, neutral detergent fibre; ADF, acid detergent fibre; ADL, acid detergent lignin; $\mathrm{N}$, nitrogen.

and analysed for N. During week 3, dacron bags (pore size $41 \times 41 \mu \mathrm{m}$ ) with 3-5 g (on DM basis) of straw, supplement, large rumen particles (size $>1.25 \mathrm{~mm}$ ), small rumen particles $(0.041 \mathrm{~mm}<\operatorname{size}<1.25 \mathrm{~mm})$ and total rumen contents were incubated for $0.5,6,12,24$, 48,72 and $96 \mathrm{~h}$ in the rumen of each steer in duplicate. The ration components incubated in each animal's rumen were those included in its diet. In another rumen-cannulated steer fed with wheat straw and sugar-beet pulp the various samples were incubated for $336 \mathrm{~h}$ to determine the truly undegradable residue (U). Straw and supplements were ground to pass through a $1 \mathrm{~mm}$ sieve, while the isolated large and small particles and total rumen contents were incubated as such. After removal of the bags from the rumen they were washed in a washing machine for 30 min with cold water.

\section{Rumen fermentation}

Rumen fluid samples were taken during week 2 for analysis of diurnal fluctuations in $\mathrm{pH}$, and $\mathrm{NH}_{3}-\mathrm{N}$ and volatile fatty acid (VFA) concentrations. Rumen fluid samples were taken two-hourly starting from $07 \cdot 30$ until 19.30 hours. The $\mathrm{pH}$ was measured immediately and samples for $\mathrm{NH}_{3}-\mathrm{N}$ and VFA analysis were centrifuged and stored with trichloroacetic acid and $14 \cdot 7 \mathrm{M}$-phosphoric acid respectively, pending further analysis.

\section{Rumen evacuations}

Rumen evacuations were done in the first and second weeks of each experimental period. Each steer's rumen was evacuated once daily over $3 \mathrm{~d}$ either at $09 \cdot 30,13 \cdot 30$ or 17.30 hours. The rumen contents were weighed, sampled and the residue returned into the rumen. This procedure took about 30 min per steer. During week $1,3 \%$ of the rumen contents were taken: $1.5 \%$ for separation into large (size $>1.25 \mathrm{~mm}$ ) and small $(0.41 \mathrm{~mm}<$ size $<1.25 \mathrm{~mm}$ ) particles and subsequent incubation in dacron bags, $0.5 \%$ for incubation in dacron bags, $0.5 \%$ for wet sieve analysis, and $0.5 \%$ for analysis of composition.

During week 2 feed was withdrawn from the animals from 09.00 till 18.00 hours during the $3 \mathrm{~d}$ when evacuations took place. A small proportion $(2 \%)$ of the rumen contents was sampled: $1 \%$ for wet sieve analysis and subsequent dacron bag analysis for $336 \mathrm{~h}$, and $1 \%$ for analysis of composition including $\mathrm{Cr}$. The rate of turnover of large and small particles was measured from the logarithmic decline in the whole rumen large and small particle pool. The rate of comminution of large particles was estimated from the logarithmic decline in the rumen undegradable large-particle pool. 
Particle size distribution

Particle size distribution of straw immediately upon ingestion and chewing was measured in week 2 by allowing the animals to consume straw for $15 \mathrm{~min}$ while having an empty rumen. The ingested material was removed from the rumen and stored as such in a freezer pending sieve analysis. Faecal samples for analysis of particle size distribution were taken once in week 1 and once in week 3.

Wet sieve analysis of rumen and faecal samples was done on a Fritsch Analysette 3 (Fritsch GmbH-Laborgerätebau, D-6580 Udar-Oberstein, Germany). The procedure was as described in detail by Bosch et al. $(1993 a)$. For faecal samples the mesh apertures of the sieves used were $1.25,0.63,0.315,0.16$ and $0.071 \mathrm{~mm}$. For rumen samples the mesh apertures were $5,2.5,1.25,0.63$ and $0.071 \mathrm{~mm}$. Rumen samples obtained immediately after ingestion were sieved through a $1.25 \mathrm{~mm}$ mesh. Separation of rumen samples into large and small particles for incubation in dacron bags was done through sieves of $1.25 \mathrm{~mm}$ and dacron cloth with a pore size of $0.041 \mathrm{~mm}$. Hence, small particles passing this dacron cloth were not included in the isolated small particles. Particles retained on sieves with a diameter larger than 1.25 are referred to as large particles (LP), while particles passing that sieve are considered small particles (SP).

The mean particle size was calculated using a logarithmic transformation of the sieve diameter as described by Waldo et al. (1971). It was assumed that material passing the $0.071 \mathrm{~mm}$ sieve should be retained on a $0.001 \mathrm{~mm}$ sieve.

\section{Chewing behaviour}

During week 1 the eating and rumination behaviour of the animals was recorded on video tape for $2 \mathrm{~d}$ for each animal: animal 1 on Monday and Thursday, animal 2 on Tuesday and Friday and animal 3 on Wednesday and Saturday. Time was also recorded on the video tapes. From these recordings the daily time spent eating and ruminating and the number of chews/min rumination were obtained. The latter was done by counting the number of chews during 1 min rumination for five rumination periods daily.

\section{Passage rates}

During the first and second weeks of each experimental period the fractional passage rates of the liquid and particulate phases in the reticulo-rumen were estimated with Co-EDTA and Cr-neutral-detergent fibre (NDF) respectively (prepared according to Udén et al. 1980). On day 1 at 06.30 hours, $100 \mathrm{~g}$ Cr-NDF $(49 \mathrm{~g} \mathrm{Cr} / \mathrm{kg}$, particle size $0 \cdot 2-1 \mathrm{~mm}$ ) and $30 \mathrm{~g}$ dry Co-EDTA $(150 \mathrm{~g} \mathrm{Co} / \mathrm{kg})$ were administered into the ventral rumen sac. Rumen fluid samples were collected every $2 \mathrm{~h}$ from 07.30 until 19.30 hours on day 1 and from 07.30 until 11.30 hours on day 2. Faecal samples for $\mathrm{Cr}$ analysis were collected over the following time intervals: on day $207.30-11.30,11.30-15.30$ and $15.30-19.30$ hours; on days 3 and 4 $19.30-07.30,07.30-11.30,11.30-15.30$ and $15.30-19.30$ hours and on day $519.30-07.30$, 07.30-13.30 and 13.30-19.30 hours. Fractional rate of passage of the liquid phase $\left(k_{l}\right)$ was derived from the logarithmic decline of the rumen Co concentration, and the fractional rate of passage of the particulate phase was estimated from the declining phase of the logarithmically transferred faecal excretion curve of $\mathrm{Cr}\left(k_{p \text {-faeces }}\right.$, peak concentration defined after plotting). No correction was made for $\mathrm{Co}$ and $\mathrm{Cr}$ withdrawal from the rumen by sampling during rumen evacuations.

The fractional rate of passage of the particulate phase was also estimated from the logarithmic decline in rumen $\mathrm{Cr}$ pool $\left(k_{p-\text { rumen }}\right)$ as estimated in animals which had no access to feed from $09.00-18.00$ hours during week 2. 


\section{Chemical analysis}

Offered and residual feed, faeces and rumen samples were analysed for DM, ash, N, NDF, acid-detergent fibre (ADF) and acid-detergent lignin (ADL). Large and small rumen particles and dacron bag residues were analysed for DM, ash and NDF. Analysis of rumen samples was done after freeze-drying, while analysis of all other samples was done after drying at $70^{\circ}$. DM was determined by drying at $103^{\circ}$, ash by ashing at $550^{\circ}$ and $\mathrm{N}$ by the Kjeldahl method. Cell wall analysis was done according to Goering \& Van Soest (1970). Hemicellulose was calculated as NDF minus ADF and cellulose as ADF minus ADL. Co in rumen fluid samples and $\mathrm{Cr}$ in faeces were determined by atomic absorption spectrophotometry (Varian SpectraA 300, wavelength $240.7 \mathrm{~nm}$ for Co and $357.9 \mathrm{~nm}$ for Cr) after wet destruction. $\mathrm{NH}_{3}-\mathrm{N}$ in rumen fluid was measured by the indophenol method (Scheiner, 1976) with a Hitachi u2000 spectrophotometer at a wavelength of $634.8 \mathrm{~nm}$. VFA were measured by GLC (Packard 419; glass column ( $1.8 \mathrm{~m}$, i.d. $2 \mathrm{~mm}$ ) filled with Chromosorb 101, 80-100 mesh, carrier gas $\left(\mathrm{N}_{2}\right)$ saturated with formic acid, $\left.190^{\circ}\right)$.

\section{Calculations and statistics}

Rates of degradation were calculated according to the model of Robinson et al. (1986):

$$
\mathbf{R}_{t}=\mathrm{U}+\mathrm{D} \times \mathrm{e}^{-k_{d} \times\left(t-t^{\prime}\right)} \text { for } t \geqslant t^{\prime}
$$

in which $\mathrm{R}_{t}$ is the residue (\%) at time $t$, $\mathrm{U}$ is the truly undegradable fraction $(\%)$, $\mathrm{D}$ is the potentially degradable, but water-insoluble fraction $(\%), k_{d}$ is the fractional rate of degradation $(\% / \mathrm{h})$ of fraction $\mathrm{D}$ and $t^{\prime}$ is the lag time (h). The model was fitted by the nonlinear regression procedure of the statistical program DBSTAT (Brouwer, 1989). The lag time was estimated as part of the model. For rumen samples no lag time was included in the model.

The rates of clearance $\left(k_{c l}\right)$ and comminution $\left(k_{c}\right)$ of large particles were calculated from the logarithmic decrease of the whole rumen LP pool and the truly undegradable rumen LP pool respectively, in fasting animals by the formulas:

$$
\ln \left(\mathbf{L} \mathbf{P}_{t}\right)=\ln \left(\mathbf{L} \mathbf{P}_{o}\right)-k_{c l} \times t
$$

in which $\mathrm{LP}_{t}$ is the size of the rumen LP NDF pool at time $t$ and $k_{c t}$ is the rate of clearance of the rumen LP NDF pool and

$$
\ln \left(\mathrm{LPU}_{t}\right)=\ln \left(\mathrm{LPU}_{\diamond}\right)-k_{c} \times t
$$

in which $\mathrm{LPU}_{t}$ is the size of the truly undegradable rumen LP NDF pool at time $t$ and $k_{c}$ is the rate of comminution.

The data were analysed statistically using the ANOVA procedure of the DBSTAT program (Brouwer, 1989). The data were analysed according to the model

$$
Y_{i j k l}=\mu+\text { period }_{i}+\text { animal }_{j}+\text { treatment }_{k}+\text { error }_{i j k l} .
$$

Total degrees of freedom (d.f.) were 8 and each of the factors and the error had 2 d.f. Significance of differences between ration means were tested by Student's $t$ test.

\section{RESULTS}

Intake and digestibility

Intake and digestibility of whole rations are presented in Table 4. Ammonia treatment increased intake of organic matter OM, NDF and cellulose and N significantly. The OM intake (OMI) of straw was $51 \cdot 1,59 \cdot 7$ and $59 \cdot 2 \mathrm{~g} / \mathrm{kg}^{0 \cdot 75}$ per day for UWS, AWS and AWSP 
Table 4. Feed intake and digestibility values, $N$ retention and average live weight of steers fed on untreated wheat straw supplemented with sugar-beet pulp (UWS), ammoniated wheat straw supplemented with sugar-beet pulp $(A W S)$ or ammoniated wheat straw supplemented with sugar-beet pulp and potato protein $(A W S P)^{*}$

(Mean values for three steers)

\begin{tabular}{|c|c|c|c|c|c|}
\hline & Diet... & UWS & AWS & AWSP & SEM \\
\hline \multicolumn{6}{|l|}{ Intake $\left(\mathrm{g} / \mathrm{kg}^{0.75}\right.$ per $\left.\mathrm{d}\right)$} \\
\hline $\mathrm{OM}$ & & $67 \cdot 8^{\mathrm{a}}$ & $76 \cdot 0^{\mathrm{b}}$ & $80 \cdot 1^{b}$ & $1 \cdot 11$ \\
\hline NDF & & $49 \cdot 8^{2}$ & $56 \cdot 4^{\mathrm{b}}$ & $56 \cdot 4^{\mathrm{b}}$ & $1 \cdot 12$ \\
\hline Hemicellulose & & 18.8 & $20 \cdot 6$ & 20.5 & 0.51 \\
\hline Cellulose & & $27 \cdot 1^{\mathrm{a}}$ & $31 \cdot 8^{\mathrm{b}}$ & $31 \cdot 8^{\mathrm{b}}$ & 0.75 \\
\hline ADL & & 3.9 & $4 \cdot 1$ & $4 \cdot 1$ & 0.06 \\
\hline $\mathbf{N}$ & & $0.72^{\mathrm{a}}$ & $1 \cdot 14^{\mathrm{b}}$ & $1.77^{\mathrm{e}}$ & 0.001 \\
\hline \multicolumn{6}{|l|}{ Digestibility (g/kg) } \\
\hline OM & & $561^{\mathrm{a}}$ & $596^{\mathrm{b}}$ & $625^{\mathrm{b}}$ & 4.9 \\
\hline NDF & & $525^{\mathrm{a}}$ & $595^{\mathrm{b}}$ & $617^{b}$ & $4 \cdot 8$ \\
\hline Hemicellulose & & $587^{\mathrm{a}}$ & $664^{\mathrm{b}}$ & $696^{\mathrm{c}}$ & $2 \cdot 8$ \\
\hline Cellulose & & $605^{\mathrm{a}}$ & $676^{\mathrm{b}}$ & $691^{\mathrm{b}}$ & 8.9 \\
\hline $\mathrm{N}$ & & $378^{\mathrm{a}}$ & $458^{\mathrm{b}}$ & $613^{c}$ & $16 \cdot 2$ \\
\hline DOMI $\left(\mathrm{g} / \mathrm{kg}^{\mathrm{0} \cdot 75}\right.$ per d) & & $38 \cdot 1^{\mathrm{a}}$ & $45 \cdot 3^{b}$ & $50 \cdot 1^{\mathrm{c}}$ & 0.40 \\
\hline $\mathrm{N}$ retained $\left(\mathrm{mg} / \mathrm{kg}^{0.75}\right.$ per $\left.\mathrm{d}\right)$ & & $68^{\mathrm{a}}$ & $81^{a}$ & $299^{\mathrm{b}}$ & $27 \cdot 2$ \\
\hline Average live wt (kg) & & 499 & 493 & 507 & 2.80 \\
\hline
\end{tabular}

OM, organic matter; NDF, neutral detergent fibre; ADL, acid detergent lignin; DOMI, digestible organic matter intake.

a,b,e Values within each row bearing unlike superscript letters were significantly different $(P<0-05)$.

* For details of diets and procedures, see Tables 2 and 3 and pp. 148-150.

respectively (SEM 1.18), which was significantly higher for AWS and AWSP than for UWS. Straw OMI increased by $16 \%$ due to ammonia treatment. No significant effect of supplementation of potato protein to ammoniated wheat straw on intake of any nutrient, except $\mathrm{N}$, was observed.

Digestibility of OM, NDF, hemicellulose, cellulose and $\mathrm{N}$ was significantly higher for AWS than for UWS. Ammonia treatment of wheat straw increased the digestibility of cellulose and hemicellulose to about the same order, by $13 \%$ for hemicellulose and by $12 \%$ for cellulose. AWSP had a significantly higher digestibility of hemicellulose and $\mathrm{N}$ than AWS. Analysis of $\mathrm{N}$ digestibility by the following Lucas equation (van Soest, 1982):

$$
\mathrm{DNI}=-a+b \times \mathrm{NI},
$$

in which DNI is the digestible $\mathbf{N}$ intake as percentage of OMI, $a$ is the intercept interpretable as the metabolic faecal $\mathrm{N}$ excretion $(\mathrm{g})$ per $100 \mathrm{~g}$ OMI, $b$ is the true digestibility of $\mathrm{N}$ and $\mathrm{NI}$ is the $\mathrm{N}$ intake ( $\%$ of $\mathrm{OMI}$ ), yielded as estimates for metabolic faecal $\mathrm{N}$ excretion 0.61 (SE 0.079 ) g/100 g OMI and for true $\mathrm{N}$ digestibility 0.88 (SE 0.051 ) $\left(\mathrm{R}^{2} 0.973\right.$, RSD 0.067, $n$ 9).

Assuming an organic matter digestibility (OMD) for the sugar-beet-pulp supplement of $850 \mathrm{~g} / \mathrm{kg}$ the estimated straw OMD was 467,525 and $545 \mathrm{~g} / \mathrm{kg}$ for UWS, AWS and AWSP respectively (SEM 7.2), which was significantly higher for AWS and AWSP than for UWS. Ammonia treatment of wheat straw increased straw OMD by $12 \%$.

Digestible organic matter intake (DOMI) was significantly higher for AWS than for UWS, while DOMI for AWSP was significantly higher than for AWS. 
Table 5. In sacco degradation characteristics of the components of fibrous rations fed to steers*

\begin{tabular}{|c|c|c|c|c|c|c|c|c|c|}
\hline & \multirow[t]{2}{*}{$\begin{array}{l}\text { Component ... } \\
\text { n... }\end{array}$} & \multicolumn{2}{|c|}{$\begin{array}{c}\text { Untreated } \\
\text { wheat straw } \\
3\end{array}$} & \multicolumn{2}{|c|}{$\begin{array}{c}\text { Ammoniated } \\
\text { wheat straw } \\
6\end{array}$} & \multicolumn{2}{|c|}{$\begin{array}{l}\text { Sugar-beet } \\
\text { pulp } \\
6\end{array}$} & \multicolumn{2}{|c|}{$\begin{array}{l}\text { Sugar-beet pulp } \\
+ \text { potato protein } \\
\qquad 2\end{array}$} \\
\hline & & Mean & SEM & Mean & SEM & Mean & SEM & Mean & SEM \\
\hline DM & $\begin{array}{l}\mathrm{D}(\%) \\
\mathrm{U}(\%) \\
k_{d}(\% / \mathrm{h}) \\
t^{\prime}(\mathrm{h})\end{array}$ & $\begin{array}{c}49 \cdot 9^{\mathrm{a}} \\
33 \cdot 9^{\mathrm{a}} \\
2 \cdot 7 \\
12 \cdot 3^{\mathrm{a}}\end{array}$ & $\begin{array}{l}2.75 \\
1.68 \\
0.23 \\
1.43\end{array}$ & $\begin{array}{c}61 \cdot 2^{\mathrm{b}} \\
23 \cdot 5^{\mathrm{b}} \\
2 \cdot 3 \\
3 \cdot 0^{\mathrm{b}}\end{array}$ & $\begin{array}{l}1.94 \\
1 \cdot 19 \\
0.16 \\
1.01\end{array}$ & $\begin{array}{r}52 \cdot 4 \\
4 \cdot 0 \\
5 \cdot 7 \\
\text { ND }\end{array}$ & $\begin{array}{l}1.00 \\
1 \cdot 06 \\
0 \cdot 18\end{array}$ & $\begin{array}{r}56-7 \\
5 \cdot 5 \\
6-2 \\
\text { ND }\end{array}$ & $\begin{array}{l}1.73 \\
1.83 \\
0.32\end{array}$ \\
\hline $\mathrm{OM}$ & $\begin{array}{l}\mathrm{D}(\%) \\
\mathrm{U}(\%) \\
k_{d}(\% / \mathrm{h}) \\
t^{\prime}(\mathrm{h})\end{array}$ & $\begin{array}{c}51 \cdot 4^{\mathrm{a}} \\
34 \cdot 5^{\mathrm{a}} \\
2 \cdot 9^{-} \\
13 \cdot 1^{\mathrm{a}}\end{array}$ & $\begin{array}{l}2.96 \\
1.86 \\
0.15 \\
1.11\end{array}$ & $\begin{array}{c}63 \cdot 1^{\mathrm{b}} \\
24 \cdot 1^{\mathrm{b}} \\
2 \cdot 5^{\mathrm{b}} \\
3 \cdot 3^{\mathrm{b}}\end{array}$ & $\begin{array}{l}2.09 \\
1.32 \\
0.11 \\
0.79\end{array}$ & $\begin{array}{r}55 \cdot 5 \\
3 \cdot 6 \\
5 \cdot 7 \\
\text { ND }\end{array}$ & $\begin{array}{l}1 \cdot 01 \\
0 \cdot 96 \\
0 \cdot 17\end{array}$ & $\begin{array}{r}59 \cdot 8 \\
4 \cdot 9 \\
6 \cdot 1 \\
\text { ND }\end{array}$ & $\begin{array}{l}1.75 \\
1.66 \\
0.30\end{array}$ \\
\hline $\mathrm{NDF}$ & $\begin{array}{l}\mathrm{D}(\%) \\
\mathrm{U}(\%) \\
k_{d}(\% / \mathrm{h}) \\
t^{\prime}(\mathrm{h})\end{array}$ & $\begin{array}{c}55 \cdot 6^{\mathrm{a}} \\
27 \cdot 0^{\mathrm{a}} \\
2 \cdot 9^{-} \\
13 \cdot 3^{\mathrm{a}}\end{array}$ & $\begin{array}{l}2.20 \\
1.40 \\
0.18 \\
0.76\end{array}$ & $\begin{array}{c}66 \cdot 1^{\mathrm{b}} \\
18 \cdot 5^{\mathrm{b}} \\
2 \cdot 6^{\mathrm{b}} \\
4 \cdot 0^{\mathrm{b}}\end{array}$ & $\begin{array}{l}1.56 \\
0.99 \\
0.13 \\
0.54\end{array}$ & & & & \\
\hline
\end{tabular}

$\mathrm{DM}$, dry matter; $\mathrm{D}$, potentially degradable fraction; $\mathrm{U}$, truly undegradable fraction; $k_{d}$, fractional rate of degradation; $t^{\prime}$, lag-time; ND, not determined; OM, organic matter; NDF, neutral detergent fibre.

${ }^{a, b}$ Mean values within each row bearing unlike superscript letters were significantly different $(P<0.05)$.

* For details of diet components and procedures, see Tables 2 and 3 and pp. 148-150.

$\mathrm{N}$ retention was significantly higher for AWSP than for AWS and UWS. The apparent utilization of digested $\mathrm{N}$, calculated as $\mathrm{N}$ retained/N digested, did not differ significantly between rations and was 226,151 and $273 \mathrm{~g} / \mathrm{kg}$ for UWS, AWS and AWSP respectively (SEM $57 \cdot 7$ ).

In Table 5 the degradation characteristics of the ration components are given. The ration components incubated in the rumen of each animal were only those that were included in its diet. Because no differences were found in degradation characteristics of ammoniated wheat straw incubated in the rumen of steers fed on AWS or AWSP the data for ammoniated wheat straw were pooled. The data for sugar-beet pulp were also pooled, since no significant difference was found between sugar-beet pulp incubated in the rumen of steers fed on UWS or AWS.

The potentially degradable fraction (D) of DM, OM and NDF was significantly higher and the truly undegradable fraction (U) and the lag time $\left(t^{\prime}\right)$ significantly lower for AWS than for UWS. The apparent solubility of DM, OM and NDF, which is equal to 100-D-U did not differ between UWS and AWS. This apparent solubility of NDF was approximately similar to that of OM. Since NDF is by definition insoluble, the apparent solubility should be attributed to escape of small particles from the bags.

Inclusion of potato protein in the sugar-beet-pulp pellet had no significant effect on DM and $\mathrm{OM}$ degradation characteristics.

\section{Degradation characteristics of rumen contents}

$\mathrm{D}$ and $k_{d}$ values of NDF in isolated LP and SP rumen particles are given in Table 6. Since the particles were isolated by wet sieving through sieves of $1.25 \mathrm{~mm}$ and $0.041 \mathrm{~mm}$ for LP and SP respectively, in this case no significant escape from dacron bags of particles at $t 0$ was observed. The average NDF disappearance for LP and SP at $t 0$ was only $0.92 \%$ (SEM 
Table 6. Potentially degradable fraction $(D)$ and rate of degradation $\left(\mathrm{k}_{\mathrm{d}}\right)$ of small $(S P)$ and large $(L P)$ neutral detergent fibre $(N D F)$ particles and $D, \mathrm{k}_{\mathrm{d}}$ and truly undegradable fraction $(U)$ of the whole rumen NDF pool in steers fed on wheat-straw-based diets*

(Mean values for three steers)

\begin{tabular}{|c|c|c|c|c|c|}
\hline & Diet... & UWS & AWS & AWSP & SEM \\
\hline SP† & $\begin{array}{l}\mathrm{D}(\%) \\
k_{d}(\% / \mathrm{h})\end{array}$ & $\begin{array}{c}55.4 \\
1.8^{\mathrm{a}}\end{array}$ & $\begin{array}{c}61.9 \\
1.8^{\mathrm{a}}\end{array}$ & $\begin{array}{c}59 \cdot 2 \\
2 \cdot 0^{\mathrm{b}}\end{array}$ & $\begin{array}{l}1.93 \\
0.02\end{array}$ \\
\hline $\mathrm{LP} \dagger$ & $\begin{array}{l}\mathrm{D}(\%) \\
k_{d}(\% / \mathrm{h})\end{array}$ & $\begin{array}{r}58 \cdot 7 \\
1.5\end{array}$ & $\begin{array}{r}69 \cdot 1 \\
2 \cdot 2\end{array}$ & $\begin{array}{r}71 \cdot 2 \\
2 \cdot 0\end{array}$ & $\begin{array}{l}3 \cdot 20 \\
0 \cdot 19\end{array}$ \\
\hline NDF pool & $\begin{array}{l}\mathrm{D}(\%) \\
\mathrm{U}(\%) \\
k_{d}(\% / \mathrm{h})\end{array}$ & $\begin{array}{c}46 \cdot 9^{\mathrm{a}} \\
36 \cdot 3^{\mathrm{a}} \\
1 \cdot 8\end{array}$ & $\begin{array}{c}55 \cdot 5^{\mathrm{b}} \\
28 \cdot 5^{\mathrm{b}} \\
1.7\end{array}$ & $\begin{array}{c}55 \cdot 4^{\mathrm{b}} \\
28 \cdot 4^{\mathrm{b}} \\
2 \cdot 1\end{array}$ & $\begin{array}{l}1.08 \\
1.25 \\
0.17\end{array}$ \\
\hline
\end{tabular}

UWS, untreated wheat straw supplemented with sugar-beet pulp; AWS, ammoniated wheat straw supplemented with sugar-beet pulp; AWSP, ammoniated wheat straw supplemented with sugar-beet pulp and potato protein.

${ }^{a}, \mathrm{~b}$ Mean values within each row bearing unlike superscript letters were significantly different $(P<0.05)$.

* For details of diets and procedures, see Tables 2 and 3 and pp. 148-152.

$\dagger \mathrm{U}=100-\mathrm{D}$.

0.436), without any significant differences between rations and between LP and SP. D and $k_{a}$ values of SP and LP did not differ significantly between UWS and AWS. Supplementation of AWS with potato protein did not affect D in SP or LP, but $k_{d}$ of SP increased significantly, though slightly.

$\mathrm{D}$ in the whole rumen NDF pool was significantly higher and $\mathrm{U}$ was significantly lower for AWSP and AWS than for UWS. The apparent solubility of the whole NDF pool, which is assumed to be escape of small particles from the dacron bags, was $16 \cdot 8,16.0$ and $16.2 \%$ for UWS, AWS and AWSP respectively. The $k_{d}$ value of the whole rumen NDF pool was not significantly different between rations.

The difference in D between SP and LP was, over rations, significantly lower than zero, indicating that D in SP was significantly lower than in LP. No significant differences between $k_{d}$ values of SP, LP and the whole rumen NDF pool were found.

\section{Rumen fermentation}

The diurnal variation in $\mathrm{NH}_{3}-\mathrm{N}$ concentration in the rumen fluid is illustrated in Fig. 1 . The $\mathrm{NH}_{3}-\mathrm{N}$ concentration in rumen fluid of steers fed on AWS or AWSP increased during the first hours after feeding and decreased gradually thereafter. The diurnal variations in $\mathrm{pH}$ and rumen VFA concentration were low.

Average daily rumen $\mathrm{pH}, \mathrm{NH}_{3}-\mathrm{N}$ and VFA concentrations are given in Table 7. UWS had a significantly lower $\mathrm{NH}_{3}-\mathrm{N}$ concentration than AWS and AWSP. No significant differences either in VFA concentration in the rumen fluid or in molar proportions of individual VFA were found between rations.

\section{Rumen pool size}

Table 8 shows the rumen pool sizes in steers that had access to the feed during the whole day. The total rumen pool size gradually declined between the morning and evening feeds and was $82 \cdot 6,78 \cdot 2$ and $74.2 \mathrm{~kg}$ at $09.30,13.30$ and 17.30 hours, respectively.

Ammoniation of wheat straw reduced total rumen pool size significantly and supplementation of potato protein to AWS significantly increased the weight of rumen 


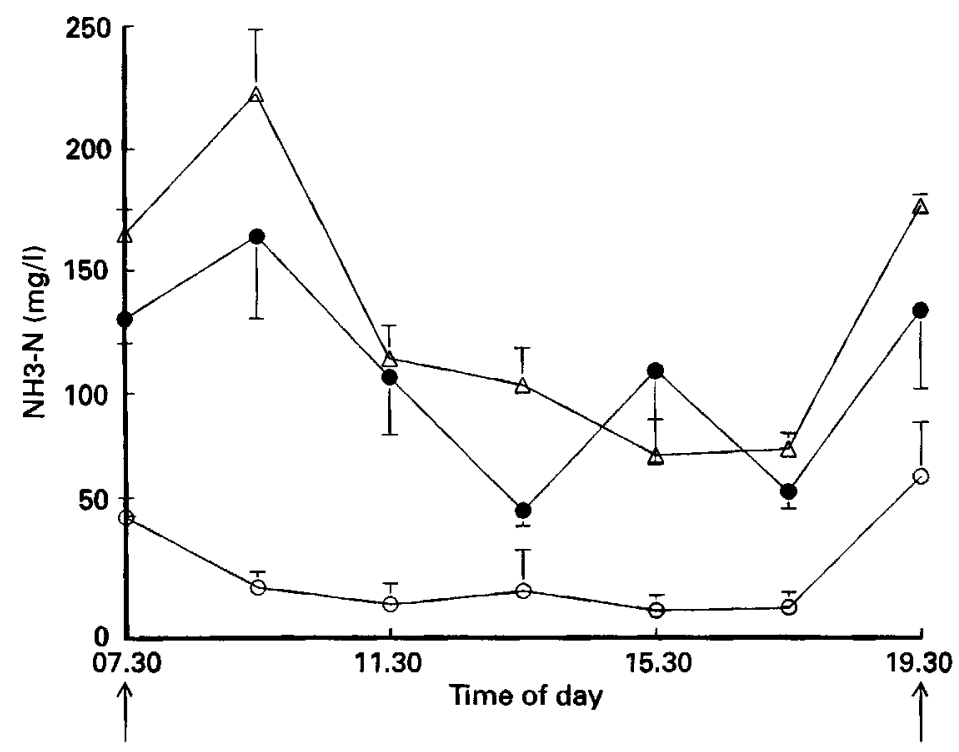

Fig. 1. Diurnal variation in $\mathrm{NH}_{3}-\mathrm{N}$ concentration in rumen fluid from steers fed on untreated wheat straw supplemented with sugar-beet pulp $(O)$, ammoniated wheat straw supplemented with sugar-beet pulp (O), or ammoniated wheat straw supplemented with sugar-beet pulp and potato protein $(\triangle)$. Arrows indicate feeding times. Values are means for three animals with standard errors indicated by vertical bars.

Table 7. Mean $\mathrm{pH}$ value, $\mathrm{NH}_{3}-\mathrm{N}$ concentration $(\mathrm{mg} / \mathrm{l})$ and volatile fatty acid (VFA) concentration (mmol/l) in rumen fluid, and molar composition of VFA (mol/100 mol) in the rumen of steers fed on wheat-straw-based diets*

(Mean values for three steers from 09.30 until 19.30 hours)

\begin{tabular}{|c|c|c|c|c|c|}
\hline & Diet... & UWS & AWS & AWSP & SEM \\
\hline $\mathrm{pH}$ & & $6 \cdot 61$ & 6.59 & 6.52 & 0.026 \\
\hline $\mathrm{NH}_{3}-\mathrm{N}$ & & $21 \cdot 1^{\mathrm{a}}$ & $103 \cdot 4^{b}$ & $125 \cdot 9^{\mathrm{b}}$ & 4.83 \\
\hline VFA & & 81.5 & 85.8 & $87 \cdot 7$ & $4 \cdot 18$ \\
\hline \multicolumn{6}{|c|}{ Molar proportions } \\
\hline $\mathrm{HAc}$ & & 73.9 & 74.7 & $74 \cdot 7$ & $0 \cdot 75$ \\
\hline HPr & & $16 \cdot 8$ & $16 \cdot 3$ & $15 \cdot 7$ & 0.57 \\
\hline $\mathrm{HBu}$ & & 8.9 & 8.7 & $9 \cdot 1$ & $0 \cdot 25$ \\
\hline $\mathrm{HVa}$ & & 0.4 & $0 \cdot 3$ & 0.4 & 0.02 \\
\hline
\end{tabular}

UWS, untreated wheat straw supplemented with sugar-beet pulp; AWS, ammoniated wheat straw supplemented with sugar-beet pulp; AWSP, ammoniated wheat straw supplemented with sugar-beet pulp and potato protein; $\mathrm{HAc}$, acetic acid; $\mathrm{HPr}$, propionic acid; $\mathrm{HBu}$, butyric acid, $\mathrm{HVa}$, valeric acid.

$a, b$ Mean values within a row bearing unlike superscript letters were significantly different $(P<0.05)$.

* For details of diets and procedures, see Tables 2 and 3 and pp. 148-152.

contents compared with AWS. Scaled to live weight, UWS had a significantly higher rumen fill than AWS, whole no significant difference between AWS and AWSP was found. No differences in pool sizes of DM, OM and cell wall constituents were observed between rations. The mean DM concentration in the rumen pool was 103,118 and $109 \mathrm{~g} / \mathrm{kg}$ (SEM 5.2) for UWS, AWS and AWSP respectively, which was not significantly different between rations. 
Table 8. Rumen pool sizes in steers fed on untreated wheat straw supplemented with sugarbeet pulp (UWS), ammoniated wheat straw supplemented with sugar-beet pulp (AWS) or ammoniated wheat straw supplemented with sugar-beet pulp and potato protein $(A W S P)^{*}$

(Mean values for three steers)

\begin{tabular}{|c|c|c|c|c|}
\hline & UWS & AWS & AWSP & SEM \\
\hline \multicolumn{5}{|l|}{ Total contents } \\
\hline (kg) & $80 \cdot 5^{\mathrm{a}}$ & $76 \cdot 3^{b}$ & $78 \cdot 1^{\mathrm{c}}$ & 0.22 \\
\hline (g/kg live wt) & $161^{a}$ & $155^{\mathrm{b}}$ & $154^{\mathrm{b}}$ & 0.7 \\
\hline \multicolumn{5}{|l|}{ DM } \\
\hline Pool > 1.25 mm (kg) & $2 \cdot 55$ & $2 \cdot 94$ & $2 \cdot 65$ & $0 \cdot 184$ \\
\hline Pool $<1.25 \mathrm{~mm}(\mathrm{~kg})$ & $5 \cdot 70$ & 6.03 & 5.81 & 1.040 \\
\hline Total $(\mathrm{kg})$ & $8 \cdot 24$ & 8.97 & $8 \cdot 45$ & 0.970 \\
\hline $\mathrm{OM}(\mathrm{kg})$ & $7 \cdot 31$ & 8.09 & $7 \cdot 54$ & 0.794 \\
\hline NDF (kg) & 5.79 & $6 \cdot 10$ & $5 \cdot 72$ & 0.660 \\
\hline Hemicellulose $(\mathrm{kg})$ & $2 \cdot 18$ & $2 \cdot 19$ & 2.07 & $0 \cdot 264$ \\
\hline Cellulose (kg) & 3.00 & $3 \cdot 24$ & 3.05 & 0.324 \\
\hline Lignin $(\mathrm{kg})$ & 0.62 & 0.67 & 0.59 & 0.073 \\
\hline
\end{tabular}

DM, dry matter; OM, organic matter; NDF, neutral detergent fibre.

$\mathrm{a}, \mathrm{b}, \mathrm{c}$ Mean values within each row bearing unlike superscript letters were significantly different $(P<0.05)$.

* For details of diets and procedures, see Tables 2 and 3 and pp. 148-151.

DM pools of LP and SP did not differ between rations. SP contributed 691, 672 and $688 \mathrm{~g} / \mathrm{kg}$ (SEM 14.2) to the total rumen DM pool for UWS, AWS and AWSP respectively. Since the NDF content of LP and SP did not differ ( 681 and $688 \mathrm{~g} / \mathrm{kg} \mathrm{DM}$ respectively), the contribution of NDF in SP to the rumen NDF pool was equal to the contribution of DM in SP to the rumen DM pool. Mean rumen particle sizes calculated according to Waldo et al. (1971) were 175,176 and $176 \mu \mathrm{m}$ for UWS, AWS and AWSP respectively (SEM 8.3, not significant). Relative contributions of particles retained on sieves with mesh apertures of (1) between 1.25 and $0.63 \mathrm{~mm}$, (2) between 0.63 and $0.071 \mathrm{~mm}$, and (3) smaller than $0.071 \mathrm{~mm}$ to the SP DM pool were averaged over rations 216 (SEM 38.1), 413 (SEM 68.7) and 363 (SEM 66.7) $\mathrm{g} / \mathrm{kg}$ respectively. This particle size distribution within the rumen SP pool did not differ significantly between rations.

\section{Chewing behaviour}

Daily time spent eating and ruminating is given in Table 9.

No significant differences emerged between rations with regard to total chewing time and eating time, either in absolute terms or when scaled to NDFI or DOMI. Rumination time was significantly higher for AWSP than for UWS, but the difference between rations disappeared when rumination time was scaled to NDFI. The number of chews/min rumination was very constant and did not differ between rations.

\section{Comminution of large particles}

Kennedy \& Poppi (1984) defined the critical particle size (CPS) as the sieve aperture retaining the top $5 \%$ of faecal particulate DM. For cattle they proposed $1.17 \mathrm{~mm}$ as CPS. In the present experiment the $1.25 \mathrm{~mm}$ sieve retained on average $4.3,4.9$ and $4.8 \%$ of the faecal particulate DM for the rations UWS, AWS and AWSP respectively.

The rate of clearance of LP, SP, and the rate of comminution $\left(k_{c}\right)$ in animals without access to feed from 09.00 till 18.00 hours and the mean faecal particle size are given in Table 
Table 9. Daily total chewing, eating and rumination times for steers fed on untreated wheat straw supplemented with sugar-beet pulp (UWS), ammoniated wheat straw supplemented with sugar-beet pulp (AWS) or ammoniated wheat straw supplemented with sugar-beet pulp and potato protein $(A W S P)^{*}$

(Mean values for three steers and two determinations per animal)

\begin{tabular}{|c|c|c|c|c|}
\hline & UWS & AWS & AWSP & SEM \\
\hline $\begin{array}{l}\text { Total chewing time: } \\
\text { min/d } \\
\mathrm{min} / \mathrm{kg} \text { NDFI } \\
\mathrm{min} / \mathrm{kg} \text { DOMI }\end{array}$ & $\begin{array}{l}833 \\
161 \\
210\end{array}$ & $\begin{array}{l}830 \\
141 \\
176\end{array}$ & $\begin{array}{l}849 \\
141 \\
159\end{array}$ & $\begin{array}{r}23 \cdot 3 \\
9 \cdot 7 \\
11 \cdot 1\end{array}$ \\
\hline $\begin{array}{l}\text { Eating: } \\
\text { min/d } \\
\min / \mathrm{kg} \mathrm{NDFI} \\
\mathrm{min} / \mathrm{kg} \text { DOMI }\end{array}$ & $\begin{array}{r}319 \\
62 \\
81\end{array}$ & $\begin{array}{r}288 \\
49 \\
61\end{array}$ & $\begin{array}{r}275 \\
46 \\
51\end{array}$ & $\begin{array}{r}24 \cdot 0 \\
6 \cdot 5 \\
7 \cdot 4\end{array}$ \\
\hline $\begin{array}{l}\text { Rumination: } \\
\min / \mathrm{d} \\
\mathrm{min} / \mathrm{kg} \text { NDFI } \\
\mathrm{min} / \mathrm{kg} \text { DOMI }\end{array}$ & $\begin{array}{r}514^{\mathrm{a}} \\
99 \\
130\end{array}$ & $\begin{array}{l}541^{\mathrm{ab}} \\
92 \\
115\end{array}$ & $\begin{array}{r}574^{\mathrm{a}} \\
96 \\
108\end{array}$ & $\begin{array}{l}6 \cdot 5 \\
3 \cdot 4 \\
4 \cdot 2\end{array}$ \\
\hline Chews/min rumination & $60 \cdot 7$ & $60 \cdot 4$ & 59.6 & 0.57 \\
\hline
\end{tabular}

NDFI, neutral detergent fibre intake; DOMI, digestible organic matter intake.

Table 10. Rates of clearance of rumen pools of small $(S P)$ and large $(L P)$ neutral detergent fibre $(N D F)$ particles, rate of comminution $\left(\mathrm{k}_{c}\right)$ of large $N D F$ particles, and mean faecal particle size in steers fed on wheat-straw-based diets*

(Mean values for three steers per diet)

\begin{tabular}{|c|c|c|c|c|}
\hline Diet... & UWS & AWS & AWSP & SEM \\
\hline Clearance rate of SP pool $(\% / h)$ & $1 \cdot 1$ & 0.5 & 0.8 & $0 \cdot 17$ \\
\hline Clearance rate of LP pool $(\% / \mathrm{h})$ & $5 \cdot 0^{\mathrm{a}}$ & $7 \cdot 8^{a b}$ & $8 \cdot 7^{b}$ & $0 \cdot 59$ \\
\hline$k_{c}(\% / \mathrm{h})$ & $4 \cdot 1$ & $6 \cdot 3$ & $7 \cdot 3$ & $0 \cdot 59$ \\
\hline Mean faecal particle size $(\mu \mathrm{m})$ & $75 \cdot 1^{\mathrm{a}}$ & $61 \cdot 9^{\mathrm{b}}$ & $58 \cdot 0^{\mathrm{h}}$ & $1 \cdot 57$ \\
\hline
\end{tabular}

UWS, untreated wheat straw supplemented with sugar-beet pulp; AWS, ammoniated wheat straw supplemented with sugar-beet pulp; AWSP, ammoniated wheat straw supplemented with sugar-beet pulp and potato protein.

${ }^{\mathrm{a}, \mathrm{b}}$ Mean values within a row bearing unlike superscript letters were significantly different $(P<0 \cdot 05)$.

* For details of diets and procedures, see Tables 2 and 3 and pp. 148-152.

10. The rate of clearance of the LP pool was significantly higher for AWSP than for UWS. Supplementation of potato protein to AWS affected neither the turnover nor the comminution rates significantly. The turnover rate of SP was significantly lower than that of LP.

Mean faecal particle size was calculated according to Waldo et al. (1971) and was significantly reduced by ammonia treatment. Potato protein supplementation did not affect the mean faecal particle size compared with AWS.

The distribution of particle sizes immediately upon ingestion was measured in cattle with an emptied rumen. The animals were allowed to eat straw for $15 \mathrm{~min}$ and the ingesta were removed immediately after swallowing. Only four samples could be obtained, two of UWS 
Table 11. Fractional rate of passage of liquid phase $\left(\mathrm{k}_{1}\right)$, particulate phase derived from faecal Cr excretion $\left(\mathrm{k}_{\mathrm{p} \text {-faeces }}\right.$ ) or decreasing rumen Cr pool during fasting $\left(\mathrm{k}_{\mathrm{p} \text {-rumen }}\right)$, rumen turnover (intake/rumen pool size) of iNDF $\left(\mathrm{k}_{\mathrm{p}-\mathrm{INDF}}\right)$ and of lignin $\left(\mathrm{k}_{\mathrm{p}-1 \mathrm{ignin}}\right)$ in steers fed on wheat-strawbased diets*

(Mean values for three steers per diet)

\begin{tabular}{|c|c|c|c|c|c|}
\hline & Diet... & UWS & AWS & AWSP & \\
\hline \multicolumn{6}{|l|}{$k_{l}(\% / \mathrm{h})$} \\
\hline Non fasting & & $8 \cdot 8^{n}$ & $10 \cdot 4^{b}$ & $9 \cdot 6^{\mathrm{ab}}$ & 0.18 \\
\hline Fasting $\dagger$ & & $9 \cdot 2^{\mathrm{a}}$ & $10 \cdot 4^{\mathrm{b}}$ & $10 \cdot 3^{b}$ & 0.13 \\
\hline \multicolumn{6}{|l|}{$k_{p-f a e c e s}(\% / h)$} \\
\hline Non fasting & & $5 \cdot 4^{\mathrm{a}}$ & $6 \cdot 1^{\mathrm{b}}$ & $6 \cdot 3^{\mathrm{b}}$ & 0.12 \\
\hline Fasting $\dagger$ & & $4 \cdot 9$ & $5 \cdot 7$ & 6.0 & $0 \cdot 19$ \\
\hline \multicolumn{6}{|l|}{$k_{p \text {-rumen }}(\% / \mathrm{h})$} \\
\hline \multicolumn{6}{|l|}{$k_{p-l N D F}(\% / \mathrm{h})$} \\
\hline $\begin{array}{l}\text { Non fasting } \\
\text { NolNDF }\end{array}$ & & $2 \cdot 6$ & $2 \cdot 4$ & 2.5 & 0.48 \\
\hline \multicolumn{6}{|l|}{$k_{p-l i g n i n}(\% / \mathrm{h})$} \\
\hline
\end{tabular}

UWS, untreated wheat straw supplemented with sugar-beet pulp; AWS, ammoniated wheat straw supplemented with sugar-beet pulp; AWSP, ammoniated wheat straw supplemented with sugar-beet pulp and potato protein.

${ }^{\mathrm{a}, \mathrm{b}}$ Mean values within each row bearing unlike superscript letters were significantly different $(P<0.05)$.

* For details of diets and procedures, see Tables 2 and 3 and pp. 148-152.

$\dagger$ Animals fasted from 09.00-18.00 hours during the first $3 \mathrm{~d}$ after introduction of the marker.

and two of AWS. On the other occasions the animals refrained from eating. The average value LP fraction of ingested feed was $562 \mathrm{~g} / \mathrm{kg}$ for UWS and $456 \mathrm{~g} / \mathrm{kg}$ for AWS (values not significantly different; SEM 47·1).

\section{Rates of passage of fluid and particulate phases}

The fractional flow rate of rumen liquid $\left(k_{l}\right)$ and particulate phases measured either from the decline in marker concentration in faeces $\left(k_{p \text {-faeces }}\right)$ or from the decline in rumen pool of $\mathrm{Cr}\left(k_{p-r u m e n}\right)$ are given in Table 11. This table indicates whether the estimates were derived from fasting animals (feed withdrawn from 09.00-18.00 hours during the first $3 \mathrm{~d}$ after introduction of the markers into the rumen) or non-fasting animals. The $k_{l}, k_{p \text {-faeces }}$ and $k_{p-r u m e n}$ were lower for UWS than for the other rations. The difference between fasting and non-fasting across rations was significantly different from zero for $k_{l}$ and $k_{p-f a c e s}$, suggesting that $k_{l}$ was significantly higher and $k_{p \text {-faeces }}$ significantly lower in fasting than in non-fasting animals. The $k_{p-r u m e n}$ measured during fasting across and within rations was significantly lower than the $k_{p \text {-faeces }}$ measured during fasting.

The rates of turnover of the rumen indigestible NDF (iNDF) pool $\left(k_{p-i N D F}\right)$ and lignin $\left(k_{p-\text { lignin }}\right)$ pool were calculated as intake/rumen pool size. For estimation of $k_{p-i N D F}$ the following assumptions were made: (1) the $U$ of straw NDF intake was estimated as $\mathrm{U} /(\mathrm{D}+\mathrm{U})$ (see Table 5), which means that the ratio $\mathrm{U}: \mathrm{D}$ of the apparently soluble part was assumed to be equal to the part that remained in the bags, (2) the U of NDF of the supplements were equal to the U of OM (see Table 5), and (3) the U of the rumen NDF pool were the weighted means (based on the proportion of particles in the rumen) of the $\mathrm{U}$ of isolated SP and LP (see Table 6). Since particles that were not retained on dacron cloth 
with a pore size of $0.041 \mathrm{~mm}$ were not included in the fraction of isolated SP, the assumption was that these very small particles had the same $\mathrm{U}$ as the isolated SP.

The $k_{p-i N D F}$ and $k_{p-\text { lignin }}$ did not differ significantly between rations. Over rations, $k_{p-i i g n i n}$ minus $k_{p-i N D F}$ was significantly higher than zero, indicating that the rate of turnover of iNDF was significantly lower than that of lignin. If the rate of turnover of the small particle iNDF pool was calculated as iNDF intake/rumen small particle iNDF pool, the derived values were $3 \cdot 7,3.6$ and $3.3 \%$ / h for UWS, AWS and AWSP respectively (SEM 0.844 , not significant). The $k_{p \text {-rumen }}$ and $k_{p \text {-faeces }}$ refer to the rumen small particle pool, since they were determined with Cr-NDF particles of a size smaller than $1.25 \mathrm{~mm}$. Both $k_{p \text {-rumen }}$ and $k_{p \text {-faeces }}$ were significantly higher than the rate of turnover of the small particle iNDF pool.

\section{DISCUSSION}

\section{Intake, digestibility and composition}

Intake and digestibility of wheat straw increased due to treatment with anhydrous ammonia. Intake of straw OM increased by $16 \%$ and digestibility of straw OM increased by $12 \%$. These increases are comparable with results of other experiments in which untreated and ammoniated wheat or barley straws were compared (Dias-da-Silva \& Sundstøl, 1986; Cottyn \& De Boever, 1988; Silva et al. 1989; Mason et al. 1990). However, Zorrilla-Rios et al. (1991) observed only an effect of ammonia treatment of wheat straw on in vitro DMD, but not on in vivo OMD.

The effect of alkaline treatment of straws is attributed to the disruption of ester bonds between hemicellulose and aromates, which can be found in the lignin portion (Chesson et al. 1983; Morrisson, 1983; Mason et al. 1990). Morrisson (1983) found after delignification a higher increase in digestibility of hemicellulose than of cellulose. This was also found by Dias-da-Silva \& Sundstøl (1986) for ammonia-treated wheat straw fed to sheep. In the present experiment a similar increase in digestibility of hemicellulose and cellulose after ammonia treatment was found as also observed by Ternrud et al. (1987).

Ammonia treatment often results in a reduction of the cell-wall fraction in the straw DM (Dias-da-Silva \& Sundstøl, 1986; Ørskov et al. 1989; Zorrilla-Rios et al. 1991), due to a reduction in hemicellulose concentration (Dias-da-Silva \& Sundstøl, 1986; Zorrilla-Rios et al. 1991). Others, however, only found a marginal reduction in cell-wall concentration (Mason et al. 1990) or hemicellulose concentration (Ternrud, 1987). In the present experiment the hemicellulose concentration decreased only marginally from 292 to $277 \mathrm{~g} / \mathrm{kg}$.

Energy intake from low quality feeds may be limited by small intestinal availability of protein (Egan, 1977; Doyle \& Panday, 1990). Increased small intestinal protein supply through supplementation with potato protein of a low rumen degradability had no significant effect on OMI and OMD of ammoniated wheat straw in the present experiment. Total DOMI increased however, and no substitution of straw intake by protein intake occurred.

The incremental intake of wheat straw as an effect of ammonia treatment has to be additionally processed in the rumen, i.e. more straw should be degraded in the rumen and/or pass undegraded from the rumen. Degradation in the rumen is a function of the fractional rate of fermentative degradation and the pool size of potentially degradable material. Microbial degradation in the rumen can be limited by $N$ or true protein availability (Hespell \& Bryant, 1979). Passage from the rumen is related to the rate at which large particles (unable to leave the rumen) are comminuted to small particles and to the rate of passage of small particles. In this respect the functional specific gravity of particles plays a predominant role (Kaske et al. 1992). 
Whether these factors related to rumen processing could explain the effects of ammonia treatment on intake and digestibility of wheat straw will be discussed in the following sections. In addition, results from the present experiment are compared with those from experiments with dairy cattle of $500-550 \mathrm{~kg}$ during late lactation reported by Bosch et al. $(1993 a, b)$. These cattle consumed wilted grass silages ad lib. and received $1 \mathrm{~kg}$ concentrate. NDF digestibility of the four silages in these experiments was on average $714 \mathrm{~g} / \mathrm{kg}$ (range $629-780 \mathrm{~g} / \mathrm{kg}$ ) and NDFI $60 \cdot 3 \mathrm{~g} / \mathrm{kg}^{0 \cdot 75}$ per d (range $49 \cdot 6-69 \cdot 5 \mathrm{~g} / \mathrm{kg}^{0 \cdot 75}$ per d), both higher than for the straws in the present experiment.

\section{Rumen degradation}

Ammonia treatment increased $D$ and decreased $U$ of wheat straw. Untreated wheat straw in the present experiment had a lower $U$ than reported by Von Keyserlingk \& Mathison (1989), who incubated for up to $120 \mathrm{~h}$, whereas ammonia-treated and untreated wheat straws had higher $U$ than reported by Ørskov et al. (1989).

$\mathrm{D}$ of the ingested straw's NDF was approximately similar to that of rumen large NDF particles, while these large NDF particles had a significantly higher D than small NDF particles. This could be explained by the fact that the average retention time in the rumen was shorter for large particles than for small particles. D of the whole rumen NDF pool was significantly higher for ammonia-treated straw-based rations than for UWS.

The lag time was reduced due to ammonia treatment, which could be related to the better rumen environment ( $N$ availability) in which the bags were incubated and a faster hydration and microbial attachment and subsequent colonization due to removal of the waxy surface layer by ammonia treatment.

The fractional rate of degradation was not significantly affected by ammonia treatment as was also apparent from the data of Ørskov et al. (1989). The rate constants of degradation of the rumen NDF pool were lower than those of ingested straw. This indicates that the absolute value of $k_{d}$ measured in the feed cannot be applied as such to the rumen contents. Aitchisson et al. (1986) concluded that estimates of $k_{d}$ derived from dacron bag incubations underestimate actual $k_{d}$ values and are at best relative indicators of the rate at which degradation occurs.

$\mathrm{D}$ and $k_{d}$ of NDF in wilted grass silages incubated in cattle during late lactation (Bosch et $a$ l. $1993 \mathrm{~b}$ ) were on average $82 \%$ and $4.5 \% / \mathrm{h}$ respectively. Comparison with values of $78 \%$ for $\mathrm{D} /(\mathrm{D}+\mathrm{U})$ and $2.6 \% / \mathrm{h}$ for $k_{d}$ of ammoniated wheat straw, indicates that ammoniated wheat straw is inferior to wilted grass silage mainly in respect of $k_{d}$ of NDF.

The rate of microbial degradation in the rumen could be affected by rumen environment. Ammoniation of wheat straw had no effect on rumen $\mathrm{pH}$, rumen VFA concentration and molar proportions of individual VFA. A rumen $\mathrm{NH}_{3}-\mathrm{N}$ concentration for maximum in vitro degradation of low quality roughages in the range of $60-100 \mathrm{mg} / 1$ was reported by Oosting et al. (1989). Hence, the rumen $\mathrm{NH}_{3}-\mathrm{N}$ concentration was lower than required for UWS, while for AWS and AWSP the rumen $\mathrm{NH}_{3}-\mathrm{N}$ concentrations were above or in the required range between the morning and evening feeding. However, the similarity of $k_{d}$ values between straws incubated in different rumen environments suggests that rumen $\mathrm{NH}_{3}-\mathrm{N}$ availability might not have limited rumen degradation for UWS. Despite the small but significant difference in $k_{d}$ of SP between AWS and AWSP, the conclusion seems also justified that rumen true protein availability was not limiting $k_{d}$ of ammoniated wheat straw either.

Rumen degradation of NDF in a steady-state situation can be described as $k_{d} /\left(k_{p}+k_{d}\right) \times\left(\mathrm{D} /(\mathrm{D}+\mathrm{U})\right.$ ) (Aitchisson et al. 1986). The $k_{d}$ values were not different between treatments and accepting similar $k_{p}$ values for the rations, the foregoing formula 
predicts a higher rumen degradation (in line with the whole tract observations) for ammonia-treated wheat-straw-based diets than for UWS as an effect of the higher D of the rumen NDF pool.

\section{Passage from the rumen}

Passage of particles from the rumen is easier for small particles and hence rate of comminution of large to small particles could limit passage. The relatively high proportion of small particles in the rumen observed for all rations indicates, however, that passage of particles from the rumen was not limited by comminution rate. Bosch et al. (1993a), who observed that the proportion of small particles in the rumen DM of dairy cattle fed on wilted grass silages was higher than $70 \%$, arrived at a similar conclusion.

The difference between mean rumen particle size $(176 \mu \mathrm{m})$ and mean faecal particle size ( $75 \mu \mathrm{m}$ for UWS and on average $60 \mu \mathrm{m}$ for rations based on ammoniated wheat straw) could at least partly be attributed to the fact that sieves used for rumen samples had a larger pore size than those used for faecal samples. However, smaller particles have a relatively higher probability of passage than larger particles (Poppi et al. 1980), which could also explain the smaller mean size for faecal than for rumen particles. Bosch et al. (1993a) observed mean faecal particle sizes varying from $25-102 \mu \mathrm{m}$ for wilted grass silages fed to dairy cattle.

The observation that the mean faecal particle size was smaller for ammonia-treated wheat-straw-based diets than for UWS, whereas no difference between rations was found with regard to particle size distribution within the rumen small particle pool, suggests that for the ammoniated wheat-straw-based rations $k_{p}$ of the smallest particles was higher than for UWS.

The rate of passage estimated by Cr-mordanted NDF was higher for rations based on ammonia-treated wheat straw than for UWS, but no ration effect on rate of passage of the indigestible NDF fraction was found. The estimates based on $\mathrm{Cr}-\mathrm{NDF}$ refer to indigestible particles in the rumen with a high functional specific gravity (FSG) and, hence, a relatively high fractional outflow rate (Sutherland, 1987). Indigestible NDF is not physically separated from digestible NDF. Fermentation gases will therefore be entrapped in iNDFcontaining particles, thus reducing the FSG and consequently the probability of passage. This means that the FSG of particles is related to the $D: U$ ratio. $D$ of the rumen NDF pool was higher for AWS and AWSP than for UWS. Passage rates of identical particles $(\mathrm{Cr}-$ NDF) could thus be different between rations, while those of iNDF could be similar. Differences in FGS between Cr-NDF and iNDF could also explain why $k_{p \text {-faeces }}$ was significantly higher than $k_{p-i N D F}$, even if the latter was expressed on basis of the rumen small particle iNDF pool.

The $k_{p-f a e c e s}$ values in the present experiment were higher than those observed for wilted grass silages in dairy cattle (average $45 \% / \mathrm{h}$ ) reported by Bosch et al. $(1993 a)$. This indicates that the probability of passage of small particles with a high functional specific gravity is not lower for straw-based diets than for diets based on higher-quality roughages. Probability of passage is more determined by FSG than by particle size (Kaske et al. 1992). Effective passage rates will therefore be more related to the average FSG in the rumen or in the rumen SP pool than to the $k_{p}$ determined by Cr-NDF.

Passage is also related to the rumen pool size of particles that can potentially leave the rumen. Rumen DM pool sizes ( $\mathrm{g} / \mathrm{kg}$ live weight) in the present experiment were $16 \cdot 5,18 \cdot 2$ and 16.7 for UWS, AWS and AWSP respectively (SEM 0.53 , not significant), in line with the average value of 17.5 reported by Bosch $e t$ al. (1993a) for wilted grass silages fed during late lactation to dairy cattle. Bosch et al. $(1993 a)$ observed a slightly higher proportion of SP in the rumen DM pool (range $74-81 \%$ ) than found in the present experiment. As 
indicated earlier, the $k_{p \text {-faeces }}$ in the present experiment was, however, higher. Effective passage of SP ( $k_{p}$ times SP-pool) from the rumen in the present experiment would therefore be approximately similar to that in the experiments of Bosch et al. (1993a).

The proportions of SP in the rumen did not differ significantly between rations, and rumination times per $\mathrm{kg}$ NDF ingested were approximately similar for all rations. This suggests that the rate of particle size reduction during rumination did not differ between rations. However, Doyle (1983) reported that the resistance to comminution reduces due to alkali treatment, as indicated by the fact that energy consumption in milling was lower for alkali-treated rice straw than for untreated rice straw. There were some weak indications of a reduced resistance to particle size comminution after ammonia treatment in the present experiment: UWS compared with AWS and AWSP had a lower rate of comminution $(P>0.05)$ and a higher (also non-significant) LP fraction immediately upon ingestion and a longer eating time per $\mathrm{kg}$ NDF ingested (also non-significant). The rates of comminution observed in the present experiment were in line with those reported by Bosch et al. (1993a) for wilted grass silages (average $5 \cdot 7 \% / \mathrm{h}$ ).

The daily time spent ruminating for the straws in the present experiment was approximately similar to that for grass silages fed to dairy cattle reported by Bosch et al. $(1993 a)$. These findings support the suggestion of Welch (1982) that the maximum duration of rumination is approximately $9-10 \mathrm{~h}$. Total chewing time/ $\mathrm{kg}$ NDFI in the experiments of Bosch et al. (1993 a) was on average $132 \mathrm{~min}$, not much different from the average value observed in the present experiment. However, average total chewing time/kg DOMI was $99 \mathrm{~min}$ in the experiments of Bosch et al. $(1993 a, b)$ and in the present experiment $182 \mathrm{~min}$. This indicates that the energy expenditure in chewing as a proportion of digestible energy intake was higher for straw-based diets than for the silages in the experiments of Bosch $e t$ al. $(1993 a, b)$, thus causing a lower efficiency of metabolizable energy utilization.

Maximum rumen fill (Bosch et al. 1993a), time required for mastication (Welch, 1982), protein:energy ratio in digestion products (Egan, 1977), energy demand in relation to physiological status (Weston, 1982) or minimized $\mathrm{O}_{2}$ consumption per unit net energy ingested (Tolkamp \& Ketelaars, 1992) are mentioned as determinants of intake of lowquality roughages. These factors are, however, often associated and falsification of any theory of intake regulation is therefore difficult.

In the present experiment rumen DM pools did not differ between rations, which could indicate that intake was limited by rumen fill. However, the total rumen pool size decreased during periods between morning and evening feeding, despite the fact that the animals had access to straw during this period. Straw intake during this period was therefore not limited by potential rumen fill, but it could be that the maximum rumen fill could not be maintained between feedings because eating time was restricted by time required for rumination.

Small-intestinal protein availability was probably different between rations. Microbial protein synthesis in the rumen is related to energy availability in the rumen, which was higher for AWS and AWSP than for UWS, and the potato protein of a low rumen degradability in AWSP increased the dietary protein availability in the small intestine. The observed differences with regard to DOMI between treatments could therefore be related to differences in small-intestinal protein availability.

The fact that DOMI differed between rations indicates that the energy demand of the growing steers was not limiting energy intake, at least for rations UWS and AWS.

$\mathrm{O}_{2}$ consumption per unit net energy intake is related to metabolizable energy losses in digestion and metabolic processes and in rumination and eating activity. The metabolizable energy losses in eating and rumination activity as indicated by the time spent ruminating $/ \mathrm{kg}$ DOMI were lower (though not significantly) for AWS and AWSP than for UWS, and were 
lower for the silages in the experiments of Bosch et al. (1993a) than for the straws in the present experiment. In addition, total metabolizable energy losses increase with decreasing quality of the feed (Agricultural Research Council, 1980). Intake differences within the present experiment and between the present experiment and those reported by Bosch $e t$ al. $(1993 a, b)$ could therefore also be related to the different levels of net energy intake, for which $\mathrm{O}_{2}$ consumption per unit net energy intake was minimal.

In conclusion, ammonia treatment increased intake and digestibility of wheat straw by steers, while potato protein supplementation to ammoniated wheat straw increased total DOMI, but had no effect on OMI and OMD of ammoniated wheat straw. The increased rumen turnover could be explained by a higher rumen degradation for ammoniated wheat straw, mainly caused by an increased D. Comparison with wilted grass silages, as an example of a better-quality roughage with a higher NDFI and NDF digestibility, showed that differences between silage and straw-based diets with regard to rate of comminution and passage characteristics were small. However, the straws offered in the present experiment had a lower $k_{d}$ than grass silages. In addition, untreated wheat straw had a lower $\mathrm{D}$ of NDF, than wilted grass silage.

The authors gratefully acknowledge financial support provided by the Commission of the European Communities: contract TS2-0091-NL, utilization of crop residues and supplementary feeds in tropical developing countries. They are further indebted to $\mathrm{Mr} \mathrm{G}$. A. Bangma and Mr D. Vink and Ms A. J. Fleurke for taking care of the fistulated animals.

\section{REFERENCES}

Agricultural Research Council (1980). The Nutrient Requirements of Ruminant Livestock. Slough: Commonwealth Agricultural Bureaux.

Aitchisson, E., Gill, M., France, J. \& Dhanoa, M. S. (1986). Comparison of methods to describe the kinetics of digestion and passage of fibre in sheep. Journal of the Science of Food and Agriculture 37, 1065-1072.

Bosch, M. W., Lammers-Wienhoven, S. C. W., Bangma, G. A., Boer, H. \& van Adrichem, P. W. M. (1993a). Influence of stage of maturity of grass silages on digestion processes in dairy cows. 2 . Rumen contents, passage rates, distribution of rumen and faecal particles and mastication activity. Livestock Production Science 32, $265-281$.

Bosch, M. W., Tamminga, S. \& van Bruchem, J. (1992). Dietary and animal factors affecting rumen capacity in dairy cows. Archives of Animal Breeding 34, $469-481$.

Bosch, M. W., Tamminga, S., Post, G., Leffering, C. P. \& Muylaert, J. M. (1993b). Influence of stage of maturity of grass silages on digestion processes in diary cows. 1. Comparison, nylon bag degradation rates, fermentation characteristics, digestibility and intake. Livestock Production Science 32, 245-264.

Brouwer, B. O. (1989). DBSTAT User's Guide. Wageningen: Department of Animal Husbandry, Agricultural University.

Cheeson, A., Gordon, A. H. \& Lomax, J. A. (1983). Substituent groups linked by alkali-labile bonds to arabinose and xylose residues of legume, grass and cereal straw cell walls and their fate during digestion by rumen microorganisms. Journal of the Science of Food and Agriculture 34, 1330-1340.

Cottyn, B. G. \& De Boever, J. L. (1988). Upgrading of straw by ammoniation. Animal Feed Science and Technology 21, 287-294.

Dias-da-Silva, A. A. \& Sundstøl, F. (1986). Urea as a source of ammonia for improving the nutritive value of wheat straw. Animal Feed Science and Technology 14, 67-79.

Doyle, P. T. (1983). Digestion of treated crop residues and the need for nutrient additions in balanced rations using such residues. In The Utilisation of Fibrous Crop Residues, pp. 69-85 [G. R. Pearce, editor]. Canberra: Australian Government Publishing Service.

Doyle, P. T. \& Panday, S. B. (1990). The feeding value of cereal straws for sheep. III. Supplementation with minerals or minerals and urea. Animal Feed Science and Technology 29, $29-43$.

Egan, A. R. (1977). Nutritional status and intake regulation in sheep. VII. Relationships between the voluntary intake of herbage by sheep and the protein/energy ratio in the digestion products. Australian Journal of Agricultural Research 28, 907-915.

Goering, H. K. \& van Soest, P. J. (1970). Forage Fiber Analysis. Agricultural Handbook no. 379. Washington DC: Agricultural Research Service, US Department of Agriculture.

Hespell, R. B. \& Bryant, M. P. (1979) Efficiency of rumen microbial growth: influence of some theoretical and experimental factors on $\mathrm{Y}_{\text {ATP. }}$. Journal of Animal Science 49, 1640-1659. 
Kaske, M., Hatiboglu, S. \& Engelhardt, W. V. (1992). The influence of density and size of particles on rumination and passage from the reticulo-rumen of sheep. British Journal of Nutrition 67, 235-244.

Kennedy, P. M. \& Poppi, D. P. (1984). Critical particle size in sheep and cattle. In Techniques in Particle Size Analysis of Feed and Digesta in Ruminants, p. 170 [P. M. Kennedy, editor]. Edmonton: Canadian Society of Animal Science.

Ketelaars J. J. M. H. \& Tolkamp, B. J. (1992). Toward a new theory of feed intake regulation in ruminants. 1. Causes of differences in voluntary feed intake; critique of current views. Livestock Production Science 30, 269-296.

Mason, V. C., Dhanoa, M. S., Hartley, R. D. \& Keene, A. S. (1990). Relationships between chemical composition, digestibility in vitro and cell-wall degradability of wheat straw treated with different amounts of ammonia and water at elevated temperature. Animal Feed Science and Technology 27, 293-306.

Morrisson, I. M. (1983). The effect of physical and chemical treatments on the degradation of wheat and barley straws by rumen liquor-pepsin and pepsin-cellulase systems. Journal of the Science of Food and Agriculture 34, $1323-1329$.

Oosting, S. J., Verdonk, J. M. H. J. \& Spinhoven, G. G. B. (1989). Effect of supplementary urea, glucose and minerals on the in vitro degradation of low quality feeds. Asian-Australasian Journal of Animal Science 2 , $583-590$

Ørskov, E. R., Kay, M. \& Reid, G. W. (1989). Prediction of intake of straw and performance by cattle from chemical analysis, biological measurements and degradation characteristics. In: Evaluation of Straws in Ruminant Feeding, pp. 155-163 [M. Chenost and P. Reiniger, editors]. Barking, Essex: Elsevier Science Publishers.

Poppi, D. P., Norton, B. W., Minson, D. J. \& Henricksen, R. E. (1980). The validity of the critical size theory for particles leaving the rumen. Journal of Agricultural Science (Cambridge) 94, 275-280.

Robinson, P. H., Fadel, J. G. \& Tamminga, S. (1986). Evaluation of mathematical models to describe neutral detergent residue in terms of its susceptibility to degradation in the rumen. Animal Feed Science and Technology $15,249-271$.

Scheiner, D. (1976). Determination of ammonia and Kjeldahl nitrogen by indophenol method. Water Research 10, 31-36.

Silva, A. T., Greenhalgh, J. F. D. \& Ørskov, E. R. (1989). Influence of ammonia treatment and supplementation on the intake, digestibility and weight gain of sheep and cattle on barley straw diets. Animal Production 48, $99-108$.

Sutherland, T. M. (1987). Particles separation in the forestomachs of sheep. In Aspects of Digestive Physiology in Ruminants, pp. 43-73 [A. Dobson and M. J. Dobson, editors]. Ithaca: Cornell University Press.

Ternrud, I. E. (1987). Degradation of untreated and alkali-treated straw polysaccharides in ruminants. $\mathrm{PhD}$ Thesis, The Swedish University of Agricultural Sciences, Uppsala, Sweden.

Tolkamp, B. J. \& Ketelaars, J. J. M. H. (1992). Towards a new theory of feed intake regulation in ruminants. 2 Costs and benefits of feed consumption: an optimization approach. Livestock Production Science 30, 297-317.

Udén, P., Colluci, P. E. \& van Soest, P. J. (1980). Investigation of chromium, cerium and cobalt as markers in digesta. Journal of the Science of Food and Agriculture 31, 625-632.

Van Soest, P. J. (1982). Nutritional Ecology of the Ruminant. Corvallis, Oregon: O \& B Books.

Von Keyserlingk, M. A. G. \& Mathison, G. W. (1989). Use of the in situ technique and passage rate constants in predicting voluntary intake and apparent digestibility of forages by steers. Canadian Journal of Animal Science 69, 973-987.

Waldo D. R., Smith, L. W., Cox, E. L., Weinland, B. T. \& Lucas, H. L. Jr. (1971). Logarithmic normal distribution for description of sieved forage materials. Journal of Dietary Science 54, 1465-1469.

Welch, J. G. (1982). Rumination, particle size and passage from the rumen. Journal of Animal Science 54, 885-894.

Weston, R. H. (1982). Animal factors affecting feed intake. In Nutritional Limits to Animal Production from Pastures, pp. 183-198. [J. B. Hacker, editor]. Slough: Commonwealth Agricultural Bureaux.

Zorrilla-Rios, J., Horn, G. W. \& McNew, R. W. (1991). Nutritive value of ammoniated wheat straw fed to cattle. Journal of Animal Science 69, 283-294. 